\title{
PLATFORM E-LEARNING KELASE METODE UNTUK PEMBELAJARAN DI SEKOLAH MENENGAH KEJURUAN
}

\author{
Riana T. Mangesa1*, M.Yusuf Mappeasse 2* \\ ${ }^{*}, 2$ Pendidikan Teknik Elektro, Universitas Negeri Makassar \\ rianamangesa@yahoo.com
}

\begin{abstract}
Abstrak
Penerapan Platform e-learning kelase di Sekolah Menengah Kejuruan (SMK) dapat memberikan banyak kemudahan dalam pembelajaran. Tujuan penelitian ini adalah menginovasi pembelajaran dalam mengunakan metode belajar platform e-learning kelase, untuk meningkatkan kualitas pembelajaran dan meningkatkan hasil belajar. Jenis penelitian ini menggunakan pendekatan kualitatif dan deskriptif, yaitu mendeskripsikan efektivitas pelaksanaan pembelajaran di SMKN. Penelitian kualitatif, mengacu Sugiyono (2009) bahwa instrumen utamanya adalah peneliti sendiri, ditambah instrumen lembar observasi berupa chek lis, dokumentasi. Metode ini untuk mendeskripsikan data kelompok belajar yang dibentuk dalam satu kelas, sehingga tidak mengisolasi individu kedalam variabel, tetapi memandangnya sebagai satu kesatuan yang bertujuan menggambarkan tentang efektivitas pelaksanaan pembelajaran platform e-learning kelase. Hasil penelitian adalah pembelajaran efektif karena pelaksanaan platform e-learning kelase, dapat menginovasi guru dalam proses belajar sehingga dapat meningkatkan kualitas pembelajaran dan meningkatkan hasil belajar peserta didik.
\end{abstract}

Kata kunci: Pembelajaran, E-learning kelase, Inovatif dan Efektif.

\begin{abstract}
Application of Kelase e-learning Platform in Vocational High School (SMK) can provide many ease of learning. The purpose of this research is to innovate learning in using learning method of ease learning platform, to improve learning quality and improve learning outcomes. This type of research uses a qualitative and descriptive approach, which describes the effectiveness of the implementation of learning in SMKN. Qualitative research, referring Sugiyono (2009) that the main instrument is the researcher himself, plus instrument observation sheet in the form of checking, documentation. This method is to describe the data of study groups formed in one class, so as not to isolate the individual into the variable, but view it as a whole that aims to describe the effectiveness of the implementation of learning platform kelase e-learning. The results of the research is effective learning because the implementation of ease learning platform, can innovate teachers in the learning process so as to improve the quality of learning and improve learning outcomes of learners.
\end{abstract}

Keywords: Learning, E-learning kelase, Innovative and Effective.

\section{PENDAHULUAN}

Peranan dan fungsi teknologi Informasi dalam bidang pendidikan sangat penting untuk pengembangan mutu pendidikan. Menurut Lehman (2007), bidang pendidikan mendapatkan dampak positif dari perkembangan teknologi informasi, sehingga mencetuskan lahirnya ide tentang electronic learning (e-learning).

Didukung Lettmayr F.C.,(2011), pengaruh perkembangan teknologi informasi cenderung mengacu pada perkembangan inovasi dan kreativitas dalam dunia pendidikan untuk melakukan pembaharuan terhadap pendidikan dan pembelajaran. Karena itu kreativitas dan inovasi adalah prasyarat untuk bertahan dalam dunia pendidikan, bahkan semakin dibutuhkan sesuai perkembangan teknologi.

Seiring perkembangan teknologi sebagai sumber belajar e-learning, kini semakin terbukti bahwa buku cetak dan 
perpustakaan di sekolah bukanlah satusatunya sumber belajar. Menurut Naz Cules, (2013), kehadiran e-learning adalah untuk mengatasi keterbatasan dalam proses belajar mengajar tradisional berbasis tatap muka yang dibatasi oleh ruang dan waktu. Oleh karena itu dapat dipergunakan untuk meningkatkan hubungan antara peserta didik dan pengajar, yang dapat dilakukan kapan saja dan di mana saja secara terkontrol (Emzir, 2011).

Berkaitan dengan proses pembelajaran, maka keberhasilan kegiatan pembelajaran pun tidak hanya ditentukan oleh faktor pengajar, melainkan sangat dipengaruhi oleh keaktifan peserta didik itu sendiri untuk menggali materi dari berbagai sumber belajar. Proses belajar merupakan interaksi pribadi antara peserta didik dan pengajar. Dalam proses belajar ini sumber belajar adalah komponen yang sangat dibutuhkan, pada pihak pengajar selalu dituntut berinovasi dalam strategi, metode dan media, sedangkan individu peserta didik senantiasa dituntut untuk belajar mandiri.

Seorang pengajar dalam melakukan kegiatan pembelajaran dapat menggunakan media pembelajaran, seperti; gambar, foto, LCD, komputer bahkan dapat menggunakan teknologi informasi. Dalam memanfaatkan komputer sebagai media pembelajaran e-learning, akan memotivasi dan memberikan kemudahan, keleluasaan dalam menggali ilmu pengetahuan, baik sebagai pengajar maupun sebagai peserta didik. Salah satu perkembangan teknologi informasi adalah teknologi jaringan komputer dan internet. Melalui internet peserta didik dapat mengakses berbagai informasi dan referensi ilmu pengetahuan yang dibutuhkan dengan cepat, sehingga dapat mempermudah proses studinya. Didukung Darmawan (2014), internet mempunyai potensi yang besar dalam elearning.

Pembelajaran berbasis komputer didukung teori behaviouristik, psikologi kognitif dan konstruktivisme. Strategi behaviouristik dapat dipergunakan dalam mengajar tentang fakta-fakta, strategi kognitif dapat dipergunakan dalam mengajarkan tentang proses dan prinsip-prinsip, dan strategi konstruktivis dapat dipergunakan untuk mengajar tingkat berfikir yang lebih tinggi yang dapat mengangkat makna personal, keadaan dan belajar kontekstual (Rusman, 2012).

Tujuan pendidikan kejuruan dalam UU No. 20 Tahun 2003, tentang pendidikan di SMK, adalah untuk mempersiapkan peserta didik terutama bekerja dalam bidang tertentu, berperan strategis dalam menyiapkan sumber daya manusia yang memiliki kreativitas tinggi dan kemandirian tangguh. Senada dengan karakteristik SMK (Depdiknas, 2009) antara lain: (a) mempersiapkan siswa terutama untuk bekerja dalam bidang tertentu; (b) didasarkan pada kebutuhan kompetensi dunia kerja; (c) hubungan dengan dunia-kerja merupakan kunci sukses; (d) responsif dan antisipatif terhadap kemajuan teknologi, (e) Learning by doing and Hands on experience; (f) membutuhkan fasilitas mutakhir untuk praktik. Didukung Arikunto Suharsimi (2000), untuk sukses memenuhi lapangan kerja, pendidikan kejuruan seharusnya menyiapkan tenaga terampil yang dibutuhkan oleh masyarakat.

Sesuai tujuan dan karakteristik pendidikan di SMK, maka seharusnya program pembelajarannya mengacu pada pendidikan berbasis kompetensi, yang menekankan pada kemampuan kompetensi yang harus dimiliki oleh peserta didik.

Pendidikan berbasis kompetensi menurut Weddel (2006) dan Abdul Majid (2008), adalah pendidikan yang 
berfokus pada hasil pembelajaran, lebih mengarah pada apa yang dilakukan peserta didik, menitik beratkan pengembangan kemampuan dalam melakukan tugas-tugas sesuai tujuan standar, yang telah ditetapkan serta adaptif terhadap perubahan. Dukungan teori-teori dalam pembelajaran yang menekankan pada tiga ranah kompetensi yang hendak dicapai, yaitu kognitif untuk pemahaman, afektif untuk sikap, psikomotor untuk keterampilan.

Berkaitan dengan proses pembelajaran, maka keberhasilan kegiatan pembelajaran pun tidak hanya ditentukan oleh faktor pengajar, melainkan sangat dipengaruhi oleh keaktifan peserta didik itu sendiri untuk menggali materi dari berbagai sumber belajar. Pengajar bukan sebagai satu- satunya sumber belajar atau sumber informasi, melainkan berperan sebagai fasilitator, dinamisator, dan motivator dalam pembelajaran.

Menurut Santrock, J.W., (2008) pembelajaran adalah suatu kombinasi yang tersusun meliputi manusiawi, sarana prasarana dan prosedur karena saling mempengaruhi untuk mencapai tujuan pembelajaran. Pembelajaran di SMK seharusnya dapat dilakukan sedemikian rupa dalam bentuk pelatihan-pelatihan untuk mempersiapkan peserta didik memasuki dunia kerja, dalam arti memiliki pengetahuan, keterampilan dan sikap yang diperlukan di dunia kerja.

Inti proses belajar di SMK adalah pelatihan. Sehingga dalam menyusun program pembelajaran pelatihan (learning to practice) proses pelatihan di SMK seharusnya memperhatikan dampak yang akan mereka hadapi, metode instruksional dan media yang memudahkan peserta didik memperoleh pengetahuan dan keterampilan baru (Buckley Roger, 2009). Pendidikan merupakan proses perkembangan manusia dengan semua potensi, melalui proses pembelajaran dapat memperoleh pengetahuan, keterampilan untuk kehidupan dirinya dan lingkungannya.

Pendekatan pembelajaran pendidikan kejuruan efektif jika; (1) peserta didik dilatih sesuai lingkungan kerja; (2) peserta didik diperkenalkan dengan situasi nyata untuk berfikir, berperasaan, berperilaku; (3) peserta didik dilatih langsung secara teratur; (4) pengalaman latihan yang dilakukan membentuk kebiasaan bekerja dan berfikir untuk meningkatkan prestasi kerja; (5) metode pembelajaran memperhatikan karakteristik peserta didik, Charles Prosser dalam Wardiman, (1998).

Kurikulum yang diterapkan di SMK mempertegas bahwa proses pembelajaran harus berpusat pada pembelajar. Sehubungan dengan hal tersebut, beberapa prinsip-prinsip kegiatan belajar mengajar perlu diperhatikan, menurut Abdul Madjid (2008) kegiatan tersebut; (a) berpusat pada peserta didik, (b) belajar dengan melakukan, (c) mengembangkan kemampuan sosial, (d) mengembangkan keingintahuan dan imajinasi, (e) mengembangkan kreativitas, ketrampilan memecahkan masalah. Didukung Naz Cules, (2013) fasilitas elearning Kelase yang menggunakan layanan e-lerning ini terhubung ke server Kelase seperti layaknya Facebook ataupun Twitter. Di dalam versi Kelase sebuah sekolah sudah dapat memiliki layanan media sosial terbatas serta layanan e-learning atau kelas maya/kelas online sendiri. Karena itu pemanfaatan teknologi internet Kelase akan memberikan kemudahan belajar, karena peserta didik dapat mengakses berbagai informasi dan referensi ilmu yang dibutuhkan dengan cepat. sehingga dapat mempermudah proses belajar. Mengacu pada prinsip- 
prinsip belajar yang dikemukakan diatas maka pengajar bukan sebagai satusatunya sumber belajar, tetapi sebagai fasilitator, dinamisator, dan motivator dalam pembelajaran.

\section{METODE PENELITIAN}

Penelitian ini menggunakan metode penelitian kualitatif yakni dengan menggunakan pendekatan studi kasus. Berusaha mendeskripsikan aktivitas untuk menghasilkan pemahaman, sesuai tujuan penelitian. Dalam penelitian ini, akan menyajikan data dalam bentuk uraian kata-kata yang dapat mengambarkan keadaan sebenarnya dan tidak menolak menggunakan angka dalam menyajikan dan menganalisi data (Sugiyono, 2010).

Jenis data dalam penelitian ini terdiri dari data primer dan data sekunder. Data primer dikumpulkan secara langsung dari informan menggunakan teknik wawancara dan observasi.Teknik pengumpulannya dilakukan dengan teknik triangulasi yang bersifat menggabungkan berbagai teknik pengumpulan dan sumber data yang ada yaitu: observasi partisipatif, wawancara, dokumentasi.Instrumen penelitian yang digunakan adalah; (1) peneliti sebagai instrumen penelitian utama; (2) lembar observasi daftar pertanyaan untuk mengamati fakta-fakta (3) dokumentasi

\section{HASIL DAN PEMBAHASAN}

Gambaran umum dan penerapan pembelajaran dengan menggunakan media kelase adalah (a) dalam penerapan sebagai sumber belajar mendapatkan dukungan dari pihak sekolah. Melalui kerjasama pihak sekolah sarana dan prasarana dapat terpenuhi. Pemahaman guru tentang penggunaan e-learning kelase merupakan komponen yang penting dalam aspek pembelajaran. (b) kesulitan pengelolaan pembelajaran dapat teratasi melalui penerapan elearning kelase sebagai sumber belajar, terbukti dapat memotivasi guru dan peserta didik dalam fungsi pembelajaran. Mengacu pada teori Lettmayr F.C. 2011), bahwa kehadiran e-learning mampu menjadikan proses pelatihan yang terfokus pada fungsi sehari-hari, dapat memperkuat kemampuan mereka yang bisa ditransfer secara berbeda dalam fungsi pembelajaran.

Selanjutkan ditemukan (c) hasil evaluasi terhadap penerapan e-learning kelase untuk proses pembelajaran mendapat respon yang sangat tinggi dari peserta didik karena dapat meningkatkan kemampuan dan pemahaman materi, (d) hasil pengamatan terhadap guru dalam pelaksanaan pembelajaran termasuk kategori sangat memuaskan, karena selain tujuan dan materi pembelajaran tercapai sesuai RPP, juga dapat mengevaluasi kemandirian belajar siswa.

Hasil ini juga didukung oleh teori yang menyatakan bahwa tujuan menggunakan e-learning dalam pembelajaran adalah untuk meningkatkan kompetensi. Oleh karena fungsi utama pembelajaran elektronik, yaitu substitusi, komplemen dan suplemen, Siahaan (2003) dan Davis, G. A., Rimm, S. B., (2011).

\section{KESIMPULAN}

$\begin{array}{ccc}\text { Dapat disimpulkan } & \text { bahwa } \\ \text { pembelajaran } & \text { efektif } & \text { karena }\end{array}$ pelaksanaan e-learning kelase, dapat menginovasi guru dalam proses belajar sehingga peserta didik termotivasi dan merespon sangat tinggi. Terjadi proses belajar mandiri pada peserta didik, sehingga dapat meningkatan kemampuan pemahaman materi sesuai indikator yang direncanakan dalam RPP. 


\section{DAFTAR PUSTAKA}

Abdul Madjid. 2008. Perencanaan Pembelajaran. Bandung: Remaja Rosdakarya Offset.

Arikunto Suharsimi. 2000. Prosedur Penelitian Suatu Pendekatan Praktik (Edisi Revisi VI). Jakarta: Bumi Aksara.

Buckley Roger and Caple Jim, 2009. Thetheory \& Practice of Training, 6th edition London N1 9JN Philadelphia, USA.

Darmawan Deny. 2014. Pengembangan E-learning. Bandung. PT Remaja Rosdakarya Offset

Davis, G. A., Rimm, S. B., \& Siegle, D. 2011. Education of the gifted and talented (6th ed.). Boston, MA: Pearson.

Depdiknas. 2009. Pembangunan Pendidikan SMK. Jakarta. Direktorat Jendral Manajemen Pendidikan Dasar dan Menengah.

Emzir, 2011. Metodologi Penelitian Pendidikan. Jakarta: PT Raja Grafindo Persada.

Lehman, Lynn. 2007. A Proactive Approach to Employee Training \& Development. Rising Sun Consultants.

Lettmayr F. Christian. 2011. Learning while working Success stories on workplace learning in Europe. Luxembourg: Publications Office of the European Union (Cedefop).
Naz Cules. 2013. Definisi Cloud Computing | Pengertian Cloud Computing. //www.blognazcules.com/definisi-cloud-computing.html. diakses 8 Maret 2017

Rusman. 2010. Model-Model Pembelajaran. PT. Raja Grafindo Persada. Jakarta

Santrock, John, W. 2008. Educational psychology and technology $2^{\text {nd }}$ edition (terjemahan Tri Wibowo, BS). Texas: McGraw-Hill Company, Inc.(buku asli terbit tahun 2004)

Sugiyono. 2010. Metode Penelitian Pendidikan (Pendekatan Kuantitatif, Kualitatif, dan R\&D). Bandung: Alfabeta

Wardiman Djojonegoro. 1998. Pengembangan sumber daya manusia melalui SMK. Jakarta: PT.Jayakarta Agung Offset.

Weddel, K.S. 2006. Competency Based Education and Content Standards. Northern Colorado Literacy Resource Centre: nclrc@stvrain.k12.co.us 